\title{
DEVELOPMENT OF ADVANCED ALLOY STEELS FOR MACHINERY
}

\author{
Yevhenii Aftandiliants, Svyatoslav Gnyloskurenko \\ National University of Life and Environmental Sciences of Ukraine, Ukraine \\ aftyev@hotmail.com, slava.vgn@gmail.com
}

\begin{abstract}
Industry and our daily life place high demands on construction materials, among which steels are the most prospective. Particularly, agricultural machinery greatly depends on high quality steels for more reliable and efficient machines. So, the development of advanced steels is an important task for material science. The present paper concerns the complex analytic and experimental study of the processes at crystallization and recrystallization in solid of alloyed structural steels, containing up to $0.4 \mathrm{wt} . \% \mathrm{C}, 2 \% \mathrm{Si}, \mathrm{Mn}$ and $\mathrm{Cr}, 0.035 \% \mathrm{~N}, 0.3 \% \mathrm{~V}$ and their relation to mechanical and operational properties. The processing of steels was undertaken at melting in an induction furnace, including varying $\mathrm{Si}, \mathrm{Mn}, \mathrm{Cr}$ content and alloying by $\mathrm{V}$ and $\mathrm{N}$, subsequent deoxidation by $\mathrm{SiCa}$ and Al. Different thermal treatment of the samples was applied, including quenching, hardening, tempering, normalization. The analysis of the established regularities allowed realizing in practice proper steel processing and providing an increased level of steel strength without reducing in plasticity. It was determined that the tensile strength of the steels was increased with increment of 80-120 MPa after normalization and of 200-250 MPa in quenched and tempered state, whereas the fatigue limit was increased by 100-120 MPa. The part of the tractor made of the processed alloy steel has shown better performance and wear resistance than commonly used carbon steel proving the effect of alloying and thermal treatment.
\end{abstract}

Keywords: structural alloy steel, alloying, heat treatment, mechanical properties.

\section{Introduction}

Steels as a constructional material are the most prospective for different applications, particularly for machinery. The main operational properties of structural steel are structurally sensitive. They are significantly dependent on the structure, which is formed by alloying and at subsequent casting crystallization, cooling and recrystallization in solid at thermal treatment.

Fundamental research is devoted to the influence of alloying elements, modifiers and impurities on the structure formation and properties of steel [1-6]. However, the research mainly covers double and triple alloying systems, excluding quantitative analytical prediction for multi-component industrial structural steels. The theory of alloying and modification [7-14] gives the possibility only to generally estimate their influence to structure formation.

The experimental research in steels is quite limited and concerns mainly the particular cases of high strength steels. The relation between the degree of alloying, structure and mechanical properties for such steels after heat and deformation treatment was of interest in [15]. It was established that the level of alloying results in different final structure of the steel (ferrite-bainite, bainite, or martensite-bainite), for which the proper thermal and deformational treatment must be selected to initiate phase transformation and matrix strengthening. Alloying by $\mathrm{C}$ and $\mathrm{Mn}$ leads to hardness increase in steels due to the effect of solid solution strengthening, as it was determined in [16].

The roles of microstructural parameters, such as phase constitutions, including ferrite, bainite, retained austenite and martensite, phase stability, and volume fractions on the strength-ductility combination were revealed in [17] for multiphase low alloy steels. It was proved that heat treatment and alloy addition play an important role to satisfy the designed criteria of high strength steels. The effect of microstructure on fatigue in the threshold region in low-alloy Cr-Mo-V steels is shown in [18]. The conflicting microstructural requirements were found for steel resistance to fatigue crack initiation and growth depending on the microstructure.

The study of structure-property relationships in commercial low-alloy bainitic-austenitic steel with high strength, ductility and toughness determined that good properties could be achieved by a carbidefree bainitic-austenitic structure as a result of isothermal heat treatment [19].

The studies above concern a multi parameter task and require numerous experiments. Therefore, it is of great importance to analytically predict the steel structure under different thermal treatments, particularly for low and medium alloy structural steels. This approach can significantly decrease the factors to be identified and controlled during the experiments. 
Following this approach, the present authors previously studied activity of alloying elements ( $\mathrm{Si}$, $\mathrm{Mn}, \mathrm{Cr}, \mathrm{N}, \mathrm{V}$ ), the effect of modifiers and impurities on the phase transformations (precipitation of the secondary phases from the supersaturated solution, diffusion mobility and solubility of the components etc.) [20] and on the structure (ferrite-pearlite, martensitic and bainite structures dependence on the austenite grain size, carbide and nitride phases distribution in ferrite etc.) [21] of steels.

All the previous findings are important to correlate with the operational properties of structural steels, i.e. strength, plasticity, fatigue, fracture toughness, wear resistance.

So, the aim of the paper is to establish the relations between phase transformations, thermo-kinetic parameters and the structure of low and medium alloy structural steels revealed in $[20 ; 21]$ and their mechanical and operational properties. It is also critical to determine the type of modification and thermal treatment to create high-quality alloy steels.

\section{Materials and methods}

The smelting of the original steels was carried out in an induction furnace of $160 \mathrm{~kg}$ with a basic lining. The chemical composition of the steels was varied by alloying and includes as follow (wt.\%): 0.19-0.37 C; 0.82-1.82 Si; 0.63-3.03 Mn; 1.01-3.09 Cr; 0.005-0.031 N; up to 0.3 V. Carbon was added in charge, whereas other elements ( $\mathrm{Si}, \mathrm{Mn}, \mathrm{Cr}, \mathrm{N}$ and $\mathrm{V}$ ) were introduced into the melt as ferroalloys at $1600{ }^{\circ} \mathrm{C}$. Deoxidation was realized in the ladle by $\mathrm{SiCa}(0.15 \mathrm{wt} . \%)$ and $\mathrm{Al}$. Processing by $\mathrm{Al}$ was carried out also to facilitate the formation of vanadium nitrides at cooling after crystallization. The chemical composition of the steels was determined using a SPAS-05 optical emission spectrometer. After melting, the steel was cast into molds at $1550{ }^{\circ} \mathrm{C}$ to obtain samples for thermal treatment and different standard mechanical testing.

The standard test bars were made in accordance with the requirements of [22] and the samples were cut to determine the mechanical properties, fatigue and wear resistance. At normal temperature the UTS100 installation was used to measure the strength and tensile limit, the relative elongation and narrowing at strain in accordance with the recommendations of [23], and impact toughness, accordingly [24].

Wear resistance was determined as in [25] by the loss of sample mass (size 10x10x25 mm) in the process of its motion under the pressure $0.2 \mathrm{MPa}$, with the speed of $0.385 \mathrm{~m} \cdot \mathrm{s}^{-1}$ against loosely fixed abrasive particles (sand particles) of 0.15 to $0.20 \mathrm{~mm}$. Time of friction - 1 hour.

Multiple correlation analyses were carried out according to the methodology in [26].

\section{Results and discussion}

The study of the chemical composition influence on the steel structure and parameters of phase transformations shown in $[20 ; 21]$ allowed to establish the quantitative dependences of the strength, plasticity and toughness related to different matrix structure, i.e.:

- ferrite-perlite, dependence on the degree of austenite alloying and the content of V-N phase, carbon content and alloying elements in ferrite at the temperature of the end of the breakdown of the supersaturated solid solution and the amount of carbide and V-N phases;

- bainite, dependence on the carbon diffusion mobility in austenite at the temperature of the beginning of bainite transformation;

- martensite, dependence on the degree of austenite alloying and content of V-N phase;

- ferrite-carbide, dependence on the size of the austenite grain and the content of V-N phase, the degree of ferrite alloying, solubility and diffusion mobility of carbon and nitrogen, the amount of carbide and nitride phase precipitation.

The analysis of the established regularities allowed realizing in practice proper steel processing and providing an increased level of steel strength without reducing in plasticity. It was proved by the results of mechanical testing summarized in Table 1, in which the numerous steel samples of different chemical composition are presented. The odd numbers of the first column correspond to the initial four carbon steels of the same C, Si, Mn, Cr content without alloying by V, whereas the even ones correspond to the alloyed steels. So, it is easy to compare the range of properties in further columns to reveal the effect of alloying and thermal treatment. The increase in the tensile strength is clearly seen for all alloy steels of 
different content with increment of 80-120 MPa after normalization and of 200-250 MPa in quenched and tempered state without decrease in plasticity characteristics (elongation, reduction of area).

\section{Mechanical properties of carbon and low-alloy structural steels}

\begin{tabular}{|c|c|c|c|c|c|c|c|c|c|c|c|c|}
\hline \multirow[t]{2}{*}{ No } & C & $\mathbf{S i}$ & Mn & $\mathrm{Cr}$ & $\mathbf{V}$ & $\mathbf{N}$ & \multirow{2}{*}{$\begin{array}{c}\text { Type of heat } \\
\text { treatment }\end{array}$} & \begin{tabular}{|r|} 
Tensile \\
strength
\end{tabular} & $\begin{array}{l}\text { Yield } \\
\text { point }\end{array}$ & $\begin{array}{l}\text { Elon- } \\
\text { gation }\end{array}$ & $\begin{array}{c}\text { Reduction } \\
\text { of area }\end{array}$ & \multirow{2}{*}{$\begin{array}{c}\text { Tough- } \\
\text { ness }\end{array}$} \\
\hline & \multicolumn{6}{|c|}{ wt. $\%$} & & \multicolumn{2}{|c|}{ MPa } & \multicolumn{2}{|r|}{$\%$} & \\
\hline 1 & \multirow{4}{*}{0.26} & \multirow{4}{*}{0.36} & \multirow{4}{*}{0.62} & \multirow{4}{*}{0.10} & - & 0.005 & \multirow{2}{*}{ Normalization } & 573 & 299 & 28 & 49 & 0.69 \\
\hline 2 & & & & & 0.09 & 0.014 & & 632 & 392 & 28 & 59 & 0.75 \\
\hline 3 & & & & & - & 0.005 & \multirow{2}{*}{$\begin{array}{l}\text { Quenching }+ \text { high } \\
\text { tempering }\end{array}$} & 595 & 350 & 19 & 52 & 0.76 \\
\hline 4 & & & & & 0.09 & 0.014 & & 800 & 629 & 18 & 48 & 0.50 \\
\hline 5 & \multirow{4}{*}{0.40} & \multirow{4}{*}{0.37} & \multirow{4}{*}{0.65} & \multirow{4}{*}{0.30} & - & 0.006 & \multirow{2}{*}{$\begin{array}{c}\text { Quenching + low } \\
\text { tempering }\end{array}$} & 1220 & - & 2.0 & 4.0 & 0.17 \\
\hline 6 & & & & & 0.10 & 0.016 & & 1600 & - & 3.0 & 5.0 & 0.25 \\
\hline 7 & & & & & - & 0.006 & \multirow{2}{*}{$\begin{array}{l}\text { Quenching }+ \text { high } \\
\text { tempering }\end{array}$} & 760 & 560 & 12 & 43 & 0.70 \\
\hline 8 & & & & & 0.10 & 0.016 & & 870 & 795 & 14.0 & 44 & 0.90 \\
\hline 9 & \multirow{4}{*}{0.30} & \multirow{4}{*}{0.30} & \multirow{4}{*}{0.60} & \multirow{4}{*}{0.90} & - & 0.004 & \multirow{2}{*}{ Normalization } & 560 & 390 & 17 & 34 & 0.4 \\
\hline 10 & & & & & 0.08 & 0.012 & & 724 & 475 & 17 & 36 & 1.4 \\
\hline 11 & & & & & - & 0.004 & \multirow{2}{*}{$\begin{array}{l}\text { Quenching }+ \text { high } \\
\text { tempering }\end{array}$} & 636 & 540 & 12 & 34 & 0.46 \\
\hline 12 & & & & & 0.08 & 0.012 & & 985 & 865 & 14 & 43 & 0.70 \\
\hline 13 & \multirow{4}{*}{0.23} & \multirow{4}{*}{0.35} & \multirow{4}{*}{1.05} & \multirow{4}{*}{0.22} & - & 0.006 & \multirow{2}{*}{ Normalization } & 567 & 375 & 22.5 & - & 0.70 \\
\hline 14 & & & & & 0.11 & 0.017 & & 665 & 445 & 23.0 & - & 0.80 \\
\hline 15 & & & & & - & 0.006 & \multirow{2}{*}{$\begin{array}{c}\text { Quenching + high } \\
\text { tempering }\end{array}$} & 675 & 496 & 18.0 & 36.0 & 0.65 \\
\hline 16 & & & & & 0.11 & 0.017 & & 840 & 725 & 18.5 & 43.5 & 0.72 \\
\hline
\end{tabular}

Fatigue failure happened due to the nucleation and propagation of cracks under a repetitive or cyclic load. The previous study $[20 ; 21]$ has shown that the origin of crack nucleation in normalized steel depends on the content of carbides in ferrite at the temperature of the end of austenite diffusion breakdown. Crack propagation depends on the content of the vanadium nitrides in ferrite, the degree of its alloying, bound energy of dislocations with the interstitial impurities and formation of a new surface in ferrite and its borders. For quenched and tempered steels, the determining factors are the degree of ferrite alloying, the solubility of carbon and nitrogen and their diffusion mobility. Crack propagation is additionally determined by the size of the austenite grains and the content of the V-N phase.

The findings above $[20 ; 21]$ allowed to analyze the established regularities and experimentally determine the role of alloying elements in fatigue failure of the present alloy structural steel. Two parts of freight cars, i.e. above-spring beams after normalization and automatic coupling bodies after high temperature tempering, produced of this steel, were tested under a cyclic load. The positive trends of alloying elements $(\mathrm{V}+\mathrm{N})$ influence the process of nucleation (Fig. $1 \mathrm{a}, \mathrm{b})$ and fatigue crack propagation (Fig. $1 \mathrm{c}, \mathrm{d}$ ) is clearly seen. It was estimated that the fatigue limit increases by 100-120 MPa.

The results of the previous study [21] predicted the effect of alloying elements on the wear resistance of structural steels. It was found that for quenched and low-tempered steels the effect is determined by the degree of solid solution alloying, the length of the martensitic needles and the content of the V-N phase. For hardened and high-tempered steels it is determined by the uniformity of distribution and dispersity of the carbide and $\mathrm{N}-\mathrm{V}$ phases. The present study experimentally proved the effectiveness of alloying that is shown in Fig. 2 as a decrease in mass sample change with alloying.

As a result of the present complex study of structure-properties relations and analysis of the established regularities low-alloyed steel 30CrNV was developed. The rolls of truck tractors made of this steel were tested to determine the wear resistance parameters (wear, average rate of wear) after different operation periods. The comparative data obtained are shown in Table 2. It is obvious that the 
present steel performs the rate of wheel wear of 2.4 times less than commonly used carbon steels; of 1.6 times less than the ones with boron carbide and of 1.2 times less than bimetallic casting rolls.

a)

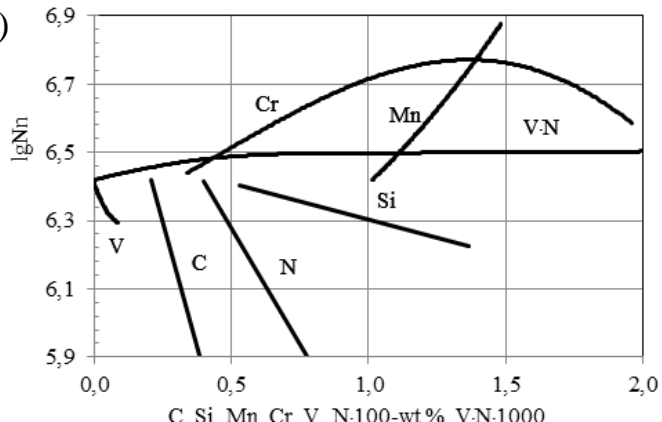

c)

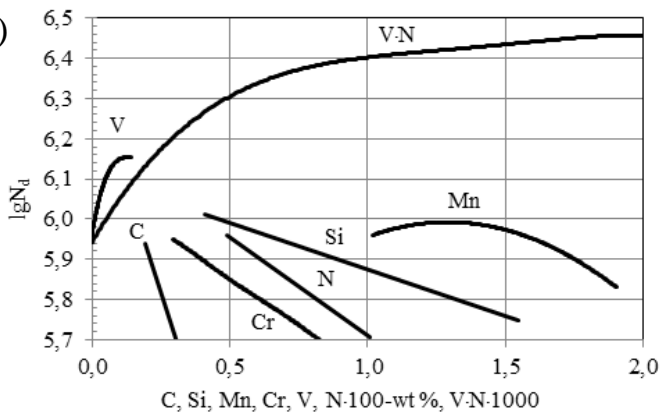

b)

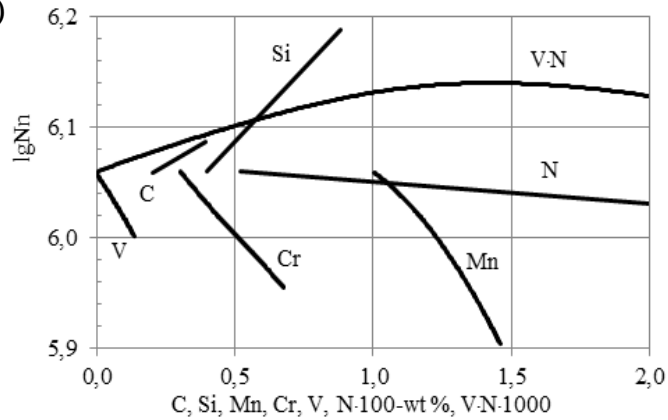

d)

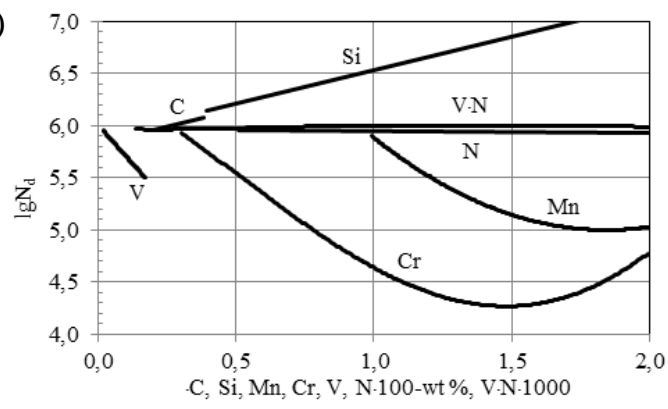

Fig. 1. Influence of alloying element content on the process of nucleation $(a, b)$ and fatigue crack propagation (c, d) in normalized above-spring beams at load force $0.2 \mathrm{MN}(\mathrm{a}, \mathrm{c})$ and high temperature tempering automatic coupling bodies at load force $0.15 \mathrm{MN}(\mathrm{b}, \mathrm{d})$ of freight cars: matrix steel contains (wt.\%): $0.2 \mathrm{C}, 0.4 \mathrm{Si}, 1 \mathrm{Mn}, 0.3 \mathrm{Cr}$; $\mathrm{Nn}$ and $\mathrm{Nd}$ - number of cycles for crack nucleation and propagation, respectively; normalization and hardening at $950{ }^{\circ} \mathrm{C}$; tempering at $650{ }^{\circ} \mathrm{C}$
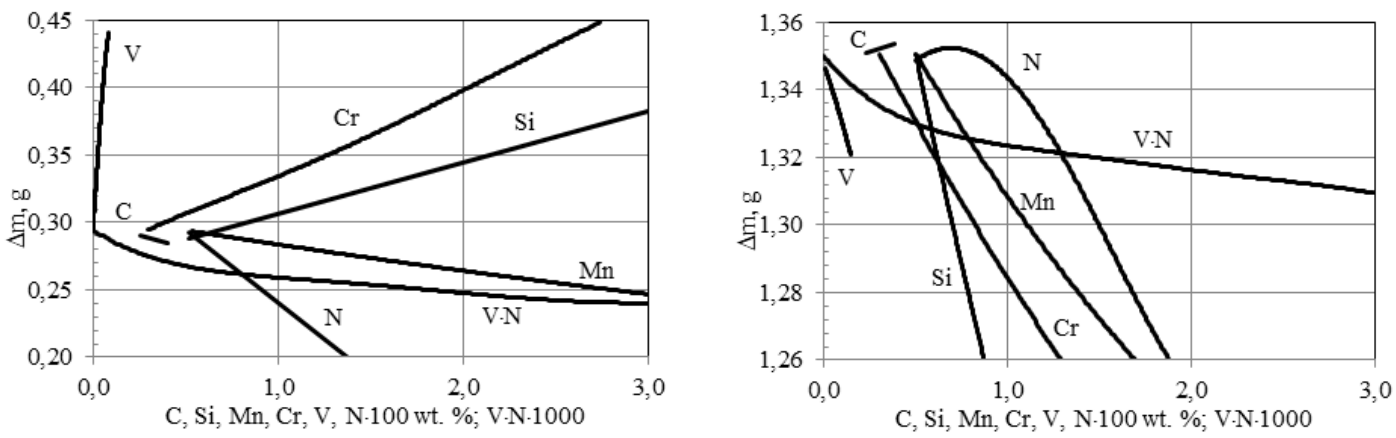

Fig. 2. Influence of alloying element contents on the wear resistance of steels: a - hardening at $950{ }^{\circ} \mathrm{C}$; tempering at $350{ }^{\circ} \mathrm{C}$; b - hardening at $950{ }^{\circ} \mathrm{C}$; tempering at $650{ }^{\circ} \mathrm{C}$; matrix steel contains (wt.\%): $0.2 \mathrm{C}, 0.5 \mathrm{Si}, 0.5 \mathrm{Mn}, 0.3 \mathrm{Cr}$. $\Delta m$ - mass change of the sample

Table 2

Exploitation test of agricultural tractors

\begin{tabular}{|l|c|c|c|}
\hline \multicolumn{1}{|c|}{ Type of roll strengthening } & $\begin{array}{c}\text { Operating time, } \\
\text { moto hours }\end{array}$ & $\begin{array}{c}\text { Wear, } \\
\text { mm }\end{array}$ & $\begin{array}{c}\text { Average rate of wear, } \\
\mathbf{1 0}^{-3} \text { mm per moto hour }\end{array}$ \\
\hline $\begin{array}{l}\text { Serial rolls of carbon steel containing } \\
\text { 0.45-0.50\% C and 0.07-0.15\% V }\end{array}$ & 5000 & 14.0 & 2.80 \\
\hline $\begin{array}{l}\text { Surface boarding of rolls } \\
\text { by boron carbide }\end{array}$ & 6500 & 12.1 & 1.85 \\
\hline $\begin{array}{l}\text { Bimetallic rolls with surface layer of } \\
\text { wear-resistant cast iron, containing } \\
16 \% \text { Cr and 2\% Mo }\end{array}$ & 3000 & 4.2 & 1.40 \\
\hline $\begin{array}{l}\text { Rolls of steel (30CrNV) } \\
\text { 0.30-0.35\% C, 1\% Cr, V + N }\end{array}$ & 6500 & 7.7 & 1.18 \\
\hline
\end{tabular}




\section{Conclusions}

The present complex study of mechanical and operational properties, i.e. strength, plasticity, fatigue, fracture toughness, wear resistance of carbon steels containing up to $0.4 \mathrm{wt} . \% \mathrm{C}, 3 \% \mathrm{Si}, \mathrm{Mn}$ and $\mathrm{Cr}$ alloyed with $\mathrm{V}$ and $\mathrm{N}$ with subsequent heat treatment, was done. The analysis of the established regularities allowed realizing in practice the proper steel processing and providing an increased level of steel strength without reducing in plasticity.

The tensile strength for the alloy steels was increased with increment of $80-120 \mathrm{MPa}$ after normalization and of 200-250 MPa in quenched and tempered state, whereas the fatigue limit increases by $100-120 \mathrm{MPa}$.

Low-alloyed 30CrNV steel was developed and testing the rolls of truck tractors revealed the wear resistance parameters increase in comparison with commonly used carbon steels and bimetallic material proving the effect of steel alloying and thermal treatment.

\section{References}

[1] ASM Handbook. Properties and Selection: Irons, Steels, and High-Performance. Carbon and LowAlloy Steels. ASM international. vol. 1, 1993, pp. 269-561.

[2] Гудремон Э. Специальные стали. (Special Steels). Москва, 1959, 1274. p. (In Russian).

[3] Меськин В.С. Основы легирования стали. (Basics of steel alloying). Москва, 1964, 684. p. (In Russian).

[4] Браун М.П. Комплекснолегированные конструкционные стали. (Complex alloyed construction steels). Киев,1965, 292. p. (In Russian).

[5] Браун М.П. Экономнолегированные стали для машиностроения. (Alloy steel for machine building). Киев, 1977, 208. p. (In Russian).

[6] Ершов Г.С., Бычков Ю.Б. Физико-химические основы рационального легирования сталей и сплавов. (Physical and chemical fundamental of rational alloying of steels and alloys). Москва,1982, 360. p. (In Russian).

[7] ASM Handbook. Alloy phase diagrams. ASM international. vol. 3, 1992, p. 1741.

[8] R. W. Cahn, P. Haasen. Physical Metallurgy. Phase Transformations in Metals. Part II. North Holland Publishing. 1983. p. 623.

[9] Editors R. W. Cahn, P. Haasen. Physical Metallurgy. Physical - Mechanical properties metals and alloys. Part III. North Holland Publishing. 1983. p. 662.

[10] Крещановский Н.С.,Сидоренко М.Ф. Модифицирование стали. (Steel Modifying). Москва,1970, 296. p. (In Russian).

[11] Курдюмов Г.В.,Утевский Л.М.,Энтин Р.И. Превращения в железе и стали. (Transformations in Iron and Steel). Москва, 1977, 236. p. (In Russian).

[12] Блантер М.Е. Теория термической обработки. (Thermal Treatment Theory). Москва,1984, 328. p. (In Russian).

[13] Садовский В.Д. Структурная наследственность в стали. (Structural heredity in steel). Москва, 1973, 208. p. (In Russian).

[14] Приходько Э.В. Металлохимия комплексного легирования. (Metall chemistry of complex alloying). Москва, 1983, 184. p.

[15] Oryshchenko A. S., Malyshevskii V. A., Petrov S. N., Shumilov E. A. Relation between the Degree of Alloying, Structure, and Mechanical Properties of High-Strength Steel. Steel in Translation, 48(3), 2018, pp.143-148.

[16] Li N., Kingkam W., Bao Z.M., Han R.H., Huang Y., Zhang H.X. Effect of Alloying Elements on Mechanical Properties of High-Strength Low-Alloy Steel. Materials Science Forum vol. 1007, 2020, pp. 41-46.

[17] Ruixian Zhu. Microstructure design of low alloy transformation-induced plasticity assisted steels. Dissertation. Texas, A\&M University. 2013 p., 149.

[18] Benson J. P., Edmonds D. V. Effect of microstructure on fatigue in threshold region in low-alloy steel, Metal Science, vol. 12(5), 1978, pp. 223-232.

[19] Sandvik B. P. J., Nevalainen H. P. Structure-property relationships in commercial low-alloy bainitic-austenitic steel with high strength, ductility, and toughness. Metals Technology, 8(1), 1981, pp. 213-220. 
[20] Aftandiliants Ye. G. Modelling of phase transformations in structural steels. Machinery \& Energetics. Journal of Rural Production Research. Scientific Herald of National University of Life and Environmental Science of Ukraine. 2020, Vol. 11, № 2, pp.C. 15-20.

[21] Aftandiliants Y. Modelling of structure forming in structural steels// Machinery \& Energetics. Journal of Rural Production Research. Scientific Herald of National University of Life and Environmental Science of Ukraine. 2020, Vol. 11, № 4, pp. 15 - 24.

[22]ГОСТ 977-88. Стандарт «Отливки стальные. Общие технические условия» (Casting steel. General technical conditions). (In Russian).

[23] ГОСТ 1497-84. Стандарт «Металлы. Методы испытаний на растяжение» (Metals. Tensile test). (In Russian).

[24] ГОСТ 9454-78. Стандарт «Металлы. Методы испытаний на ударный изгиб при пониженных, комнатной и повышенных температурах» (Metals. Impact bending testing methods at low, room and elevated temperatures). (In Russian).

[25]ГОСТ 23.208-79. «Обеспечение износостойкости изделий. Метод испытания материалов на износостойкость при трении о нежестко закрепленные абразивные частицы» (Ensuring of wear resistance of products. Wear resistance testing of materials by friction against loosely fixed abrasive particles). (In Russian).

[26] Шведков Е.Л. Элементарная математическая статистика в экспериментальных задачах материаловедения. (Elementary mathematical statistics in experimental tasks of material science), Киев, 1975, 111. p. (In Russian). 